\title{
ONE-STEP GREEN SYNTHESIS OF GRAPHENE/ZnO NANOCOMPOSITES FOR NON-ENZYMATIC HYDROGEN PEROXIDE SENSING
}

\author{
ENOSTOPENJSKA ZELENA SINTEZA NANOKOMPOZITA \\ GRAFEN-ZnO ZA NEENCIMATSKO DETEKCIJO VODIKOVEGA \\ PEROKSIDA
}

\author{
Sze Shin Low ${ }^{1}$, Michelle T. T. Tan1, Poi Sim Khiew ${ }^{1}$, Hwei-San Loh², \\ Wee Siong Chiu ${ }^{3}$
}

${ }^{1}$ Division of Materials, Mechanics and Structures, Center of Nanotechnology and Advanced Materials, Faculty of Engineering, University of Nottingham Malaysia Campus, Jalan Broga, 43500 Semenyih, Selangor, Malaysia

${ }^{2}$ School of Biosciences, Faculty of Science, University of Nottingham Malaysia Campus, Jalan Broga, 43500 Semenyih, Selangor, Malaysia ${ }^{3}$ Low Dimensional Materials Research Center, Department of Physics, Faculty of Science, University Malaya, 50603 Kuala Lumpur, Malaysia michelle.tan@nottingham.edu.my

Prejem rokopisa - received: 2014-10-14; sprejem za objavo - accepted for publication: 2014-11-17

doi: $10.17222 / \mathrm{mit} .2014 .259$

\begin{abstract}
In the present study, a disposable electrochemical biosensor for hydrogen peroxide $\left(\mathrm{H}_{2} \mathrm{O}_{2}\right)$ was fabricated using a graphene/ZnO nanocomposite-modified screen-printed carbon electrode (SPCE). The adopted method is simple, cost feasible and it avoids the usage of harsh oxidants/acids during the synthesis. Graphite material was subjected to liquid-phase exfoliation with the aid of ultrasonication, without going through the intermediate graphene-oxide phase that can disrupt the pristine structure of the yield. The as-prepared graphene/ZnO nanocomposite was then thoroughly characterized to evaluate its morphology, crystallinity, composition and product purity. All the results clearly indicate that pristine graphene was successfully produced with the graphite exfoliation and $\mathrm{ZnO}$ nanoparticles were homogeneously distributed on the graphene sheet, without any severe aggregation. The biosensing capability of the graphene/ZnO nanocomposite-modified SPCE was electrochemically evaluated with cyclic voltammetry $(\mathrm{CV})$ and an amperometric analysis. The resulting electrode is found to exhibit an excellent electrocatalytic activity towards the reduction of $\mathrm{H}_{2} \mathrm{O}_{2}$. The graphene/ZnO-modified SPCE can detect $\mathrm{H}_{2} \mathrm{O}_{2}$ in a linear range of $1 \mathrm{mM}$ to $15 \mathrm{mM}$ with a correlation coefficient of 0.9859 . The electrode is found to have a high sensitivity, selectivity and superior reproducibility for the non-enzymatic detection of an $\mathrm{H}_{2} \mathrm{O}_{2}$ compound.

Keywords: graphene/ZnO nanocomposite, sonochemical facile synthesis, electrochemical sensor, screen-printed carbon electrode, hydrogen peroxide
\end{abstract}

V predstavljeni študiji je bil izdelan elektrokemijski biosensor za enkratno uporabo za zaznavanje vodikovega peroksida $\left(\mathrm{H}_{2} \mathrm{O}_{2}\right)$ z uporabo sitotiskane ogljikove elektrode (SPCE), modificirane z nanokompozitom grafen-ZnO. Ta prilagojena metoda je enostavna, stroškovno ugodna in omogoča, da se izognemo uporabi ostrih snovi, oksidanti-kislina, med sintezo. Grafitni material je bil izpostavljen ultrazvočni obdelavi, luščenju v tekoči fazi, ne da bi bil šel skozi vmesno fazo grafenovega oksida, ki lahko moti neokrnjeno zgradbo pridelka. Pripravljeni nanokompozit grafen-ZnO je bil nato skrbno karakteriziran, ocenjena je bila morfologija, kristaliničnost, sestava in tudi čistost proizvoda. Rezultati jasno kažejo, da je bil neokrnjen grafen izdelan z glajenjem grafita, $\mathrm{ZnO}$ nanodelci pa so bili homogeno razporejeni na ploščici iz grafena brez večjih segregacij. Biološka občutljivost ploščice SPCE, modificirane z nanokompozitom grafen-ZnO, je bila ugotovljena elektrokemijsko s ciklično voltametrijo (CV) in amperometrično analizo. Ugotovljeno je bilo, da ima dobljena elektroda odlično elektrokatalitičnost za redukcijo $\mathrm{H}_{2} \mathrm{O}_{2}$. SPCE, modificirana $\mathrm{z}$ grafen- $\mathrm{ZnO}$, lahko zazna $\mathrm{H}_{2} \mathrm{O}_{2} \mathrm{v}$ linearnem področju od $1 \mathrm{mM}$ do $15 \mathrm{mM}$ sorelacijskim koeficientom 0,9859 . Ugotovljeno je bilo, da ima elektroda veliko občutljivost, selektivnost in boljšo ponovljivost pri neencimatski detekciji spojine $\mathrm{H}_{2} \mathrm{O}_{2}$.

Ključne besede: nanokompozit grafen-ZnO, sonokemijska sinteza, elektrokemijski senzor, sitotiskarsko natisnjena ogljikova elektroda, vodikov peroksid

\section{INTRODUCTION}

Graphene, a 2D one-atom-thick sheet of $\mathrm{sp}^{2}$ carbon atoms arranged in a honeycomb lattice, was discovered by Novoselov et al. ${ }^{1}$ in 2004 . Ever since, it has intrigued enormous scientific activities due to its extraordinary properties. Graphene-based composites are anticipated to provide groundbreaking properties in new applications as they improve those of the host material.

Zinc oxide ( $\mathrm{ZnO})$, a II-VI compound semiconductor has been receiving considerable attention in the scientific community due to its unique properties. The wide-band- gap properties of $\mathrm{ZnO}$ have triggered tremendous research attention for its potential applications in electronic and optoelectronic devices. Besides, $\mathrm{ZnO}$ is also popular in the field of biosensing because it is biocompatible, biodegradable, biosafe as it can be dissolved into mineral ions within a few hours. ${ }^{2}$

For the purpose of hybridization of graphene with $\mathrm{ZnO}$, researchers explored unique attractive properties like enhanced photocatalytic performance, ${ }^{3}$ energy-storage property, ${ }^{4}$ sensing property, ${ }^{5}$ optoelectronic property $^{6}$ and ultrafast, nonlinear, optical switching property. ${ }^{7}$ These intriguing properties of the composite are due to 
the synergistic effect between graphene and $\mathrm{ZnO}$, in which the carbon-based material acts as a good electron conductor and when coupled with a metal oxide, the charge transfer between the materials is improved.

There are many synthesis routes to combine graphene sheets and $\mathrm{ZnO}$ nanoparticles such as thermal decomposition, ${ }^{8}$ electrochemical route, ${ }^{9}$ ultrasonic spray pyrolysis, ${ }^{10}$ electro-hydrodynamic atomization ${ }^{11}$ and solvothermal process. ${ }^{12}$ However, most of the attempts in the synthesis of a graphene/ $\mathrm{ZnO}$ nanocomposite involve a reduction of the graphene oxide and an in-situ growth of $\mathrm{ZnO}$ which culminate in the presence of an oxygenated functional group on the graphene surface and impurities in the composite due to an incomplete reduction and purification process.

In this work, a graphene/ZnO nanocomposite was synthesised with one-step, low-cost, green approach, in which conductive graphene sheets serve as superior platforms for a deposition of flower-like $\mathrm{ZnO}$ nanoparticles. In comparison with the other work reporting on the synthesis of a graphene/ZnO composite, this synthesis method is novel and environmentally friendly because it omits the use of harsh chemicals for the exfoliation of graphite and growth of $\mathrm{ZnO}$, resulting in a safer synthetic procedure and also preserving the pristine quality of both materials. From an economical perspective, the starting materials are inexpensive, while ultrasonication does not consume much power and can be conducted in a laboratory or scaled for a mass production. The as-synthesized graphene/ $\mathrm{ZnO}$ nanocomposite was used to modify electrodes to demonstrate its viability for biosensing applications.

\section{METHODOLOGY}

\subsection{Preparation of graphene and a graphene/ZnO nanocomposite}

Graphite flakes (Bay Carbon, USA) were subjected to the one-step, green liquid-phase exfoliation method to synthesize graphene. ${ }^{13}$ Graphite flakes were added into an optimized mixture of ethanol and deionized (DI) water (ratio 2 to 3 ) and sonicated for $3 \mathrm{~h}$. The mixture was then centrifuged and washed with ethanol and DI water twice. The sediment was dried at $80{ }^{\circ} \mathrm{C}$ overnight and the graphene was collected.

The as-synthesized graphene was re-dispersed into ethanol via sonication. The graphene dispersion was then mixed with the zinc oxide $(\mathrm{ZnO})$ dispersion and further sonicated to achieve an even mixing. The mixture was then subjected to mechanical stirring for $4 \mathrm{~h}$ for the synthesis of a graphene/ZnO nanocomposite. Next, the mixture was centrifuged and washed with ethanol and DI water twice. The graphene/ZnO nanocomposite was collected after drying at $80{ }^{\circ} \mathrm{C}$ overnight.

The as-synthesized graphene and graphene/ZnO nanocomposite were characterized via scanning electron microscopy (SEM), transmission electron microscopy (TEM) and X-ray diffractometry (XRD).

\subsection{Electrochemical measurements}

The electrochemical performances of the samples in connection with cyclic voltammetry (CV) and amperometry were analyzed with AUTOLAB PGSTAT302N. A planar screen-printed carbon electrode (SPCE) was fabricated (ScrintTechnology, Malaysia) based on the design described by Chan et al. ${ }^{14} 2 \mu \mathrm{L}$ of the as-prepared graphene/ZnO nanocomposite dispersion was dropped onto the surface of the working SPCE and dried at ambient temperature.

\section{RESULTS AND DISCUSSIONS}

\subsection{Morphological analysis}

A detailed morphology of the samples was studied with SEM and TEM, as shown in Figure 1. It can be observed in Figure 1a that graphene has a flat lamellar structure which provides graphene with a large surface to accommodate the hybridization with $\mathrm{ZnO}$. The transparent nature of graphene shown in Figure 1b implies that graphite was fully exfoliated into a few layer sheets. Figure 1c shows that $\mathrm{ZnO}$ nanoparticles are dispersed on the graphene nanosheets. Figure 1d also demonstrates that the graphene sheets and $\mathrm{ZnO}$ nanoparticles are closely in contact with each other, which is beneficial for the electron transfer. Furthermore, no $\mathrm{ZnO}$ nanoparticles are observed outside the graphene sheets, suggesting a successful hybridization of the graphene/ZnO nanocomposite.
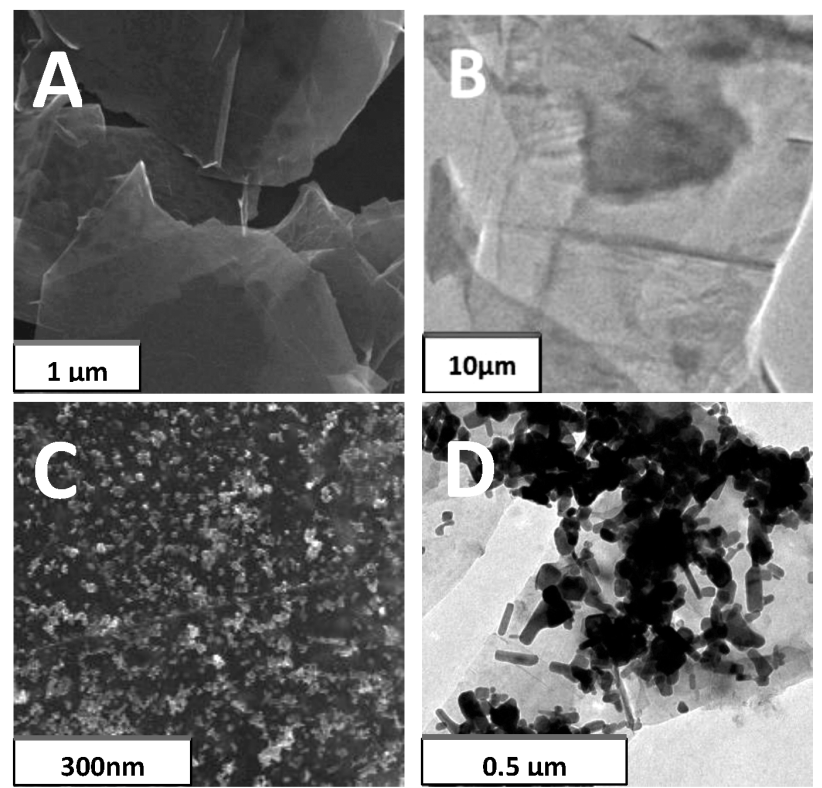

Figure 1: SEM and TEM images of the: a), b) as-produced graphene and c), d) as-synthesized graphene/ZnO nanocomposite

Slika 1: SEM- in TEM-posnetka: a), b) izdelanega grafena in c), d) sintetiziranega nanokompozita grafen- $\mathrm{ZnO}$ 


\subsection{Structural analysis}

The crystalline structure of the as-synthesized graphene/ZnO nanocomposite was corroborated with an XRD measurement. The XRD pattern of the graphene/ZnO nanocomposite is shown in Figure 2, in comparison with graphite, graphene and $\mathrm{ZnO}$ as the references. Figure 2 manifests diffraction peaks located at $2 \theta=\left(31.88^{\circ}, 34.50^{\circ}, 36.35^{\circ}, 47.60^{\circ}, 56.67^{\circ}, 62.94^{\circ}\right.$, $66.45^{\circ}, 68.01^{\circ}$ and $69.18^{\circ}$ ), which correspond to the crystal planes (002), (202), (501), (640), (660), (901), (931), (1000) and (941) of the hexagonal wurtzite structure of $\mathrm{ZnO}$ (ICSD no. 98-006-5172). Additional peaks at $2 \theta=26.63^{\circ}$ and $54.71^{\circ}$ account for the graphitic reflection of the (002) plane, corresponding to a $d$-spacing of $0.334 \mathrm{~nm}$. It is also illustrated that the XRD pattern of the graphene/ $\mathrm{ZnO}$ nanocomposite is similar to those of graphite, graphene and $\mathrm{ZnO}$, indicating that the synthesis method employed retained the pristine crystalline structures of the materials. This is crucial as lattice disruptions and crystalline-structure deformations can introduce defects that adversely affect the desired properties of the materials. The XRD data of the as-synthesized nanocomposite shows the absence of impurities, reflecting its high quality.

\subsection{Electrochemical measurement}

Cyclic voltammetry (CV) was recorded at room temperature for bare, graphene, $\mathrm{ZnO}$ and graphene/ZnO nanocomposite-modified SPCEs. The CV analyses were performed at a scan rate of $50 \mathrm{mV} / \mathrm{s}$ in the potential range of $-0.4 \mathrm{~V}$ to $0.4 \mathrm{~V}$. The redox reactions of $\mathrm{H}_{2} \mathrm{O}_{2}$ occur at very high switching potentials and therefore, for non-enzymatic $\mathrm{H}_{2} \mathrm{O}_{2}$ sensors, the maximum current is normally used for determining the sensing ability. ${ }^{15}$ Figure 3 shows that the graphene/ $\mathrm{ZnO}$ nanocompo-

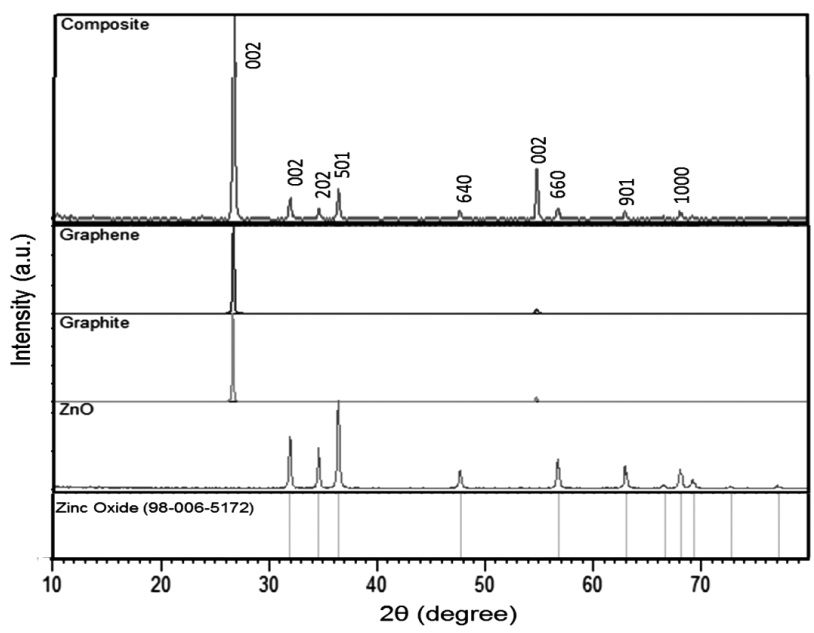

Figure 2: XRD patterns of graphite, graphene, $\mathrm{ZnO}$ and as-synthesized graphene/ZnO nanocomposite with the standard reference pattern

Slika 2: Rentgenski posnetki grafita, grafena, $\mathrm{ZnO}$ in sintetiziranega nanokompozita grafen-ZnO s standardnim referenčnim vzorcem

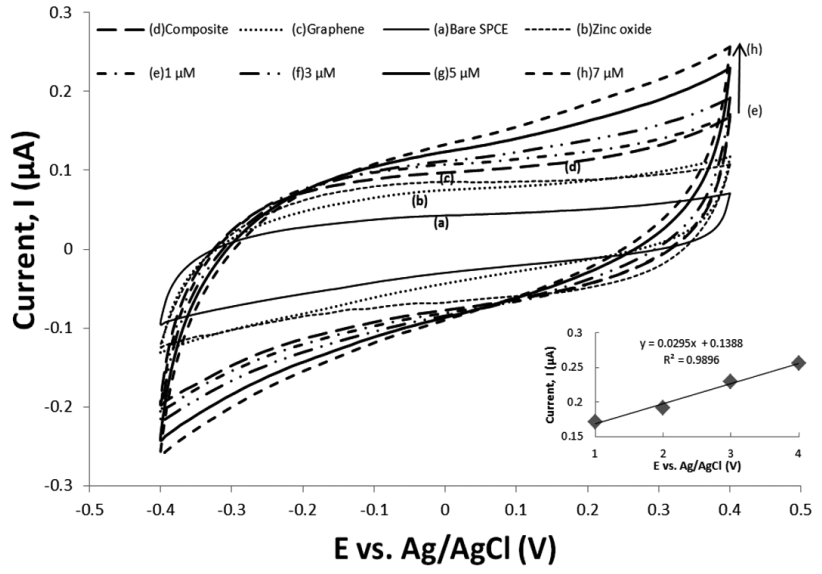

Figure 3: Cyclic voltammograms of: a) bare, b) $\mathrm{ZnO}$, c) graphene, d) graphene/ZnO nanocomposite-modified SPCE in PBS buffer and cyclic voltammograms of graphene/ $\mathrm{ZnO}$ nanocomposite-modified SPCE in the presence of: e) $1 \mu \mathrm{M}, \mathrm{f}) 3 \mu \mathrm{M}$, g) $5 \mu \mathrm{M}$, h) $7 \mu \mathrm{M} \mathrm{H}_{2} \mathrm{O}_{2}$. Inset shows the plot of the peak current against $\mathrm{H}_{2} \mathrm{O}_{2}$ concentration. Slika 3: Ciklični voltamogrami: a) goli, b) $\mathrm{ZnO}$, c) grafen, d) SPCE, modificiran z nanokompozitom grafen-ZnO v PBS-pufru. Ciklični voltamogrami modificiranega SPCE nanokompozita grafen-ZnO ob prisotnosti: e) $1 \mu \mathrm{M}$, f) $3 \mu \mathrm{M}$, g) $5 \mu \mathrm{M}$, h) $7 \mu \mathrm{M} \mathrm{H} \mathrm{H}_{2} \mathrm{O}_{2}$. Vstavek prikazuje diagram toka proti koncentraciji $\mathrm{H}_{2} \mathrm{O}_{2}$.

site-modified SPCE exhibits the greatest enhancement in terms of the electrochemical performance, with the highest peak currents (the maximum currents) being detected for both forward and reverse scans. There is a significant increase in the peak current by almost 2.5 times in the $\mathrm{CV}$ response of the composite-modified SPCE if compared to the bare electrode. On the other hand, the CV response of the graphene/ZnO nanocomposite-modified SPCE in different concentrations of $\mathrm{H}_{2} \mathrm{O}_{2}$ is also illustrated in Figure 3. The maximum current increased gradually upon increasing the concentration of $\mathrm{H}_{2} \mathrm{O}_{2}$ from (1 to 3,5 and 7) $\mu \mathrm{M}$ (Figure 3

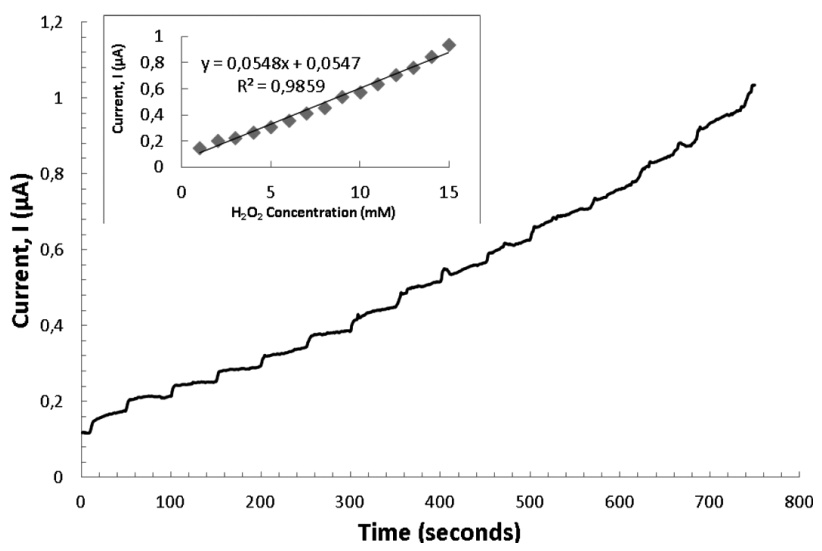

Figure 4: Amperometric $i-t$ response of graphene/ $\mathrm{ZnO}$ nanocomposite-modified SPCE to the additions of different $\mathrm{H}_{2} \mathrm{O}_{2}$ concentrations at an applied potential of $0.4 \mathrm{~V}$. Inset shows a plot of concentration of $\mathrm{H}_{2} \mathrm{O}_{2}$ versus current in the linear range.

Slika 4: Amperometričen odgovor $i-t$ SPCE, modificiranega z nanokompozitom grafen- $\mathrm{ZnO}$, pri dodatku različnih koncentracij $\mathrm{H}_{2} \mathrm{O}_{2}$ pri uporabljenem potencialu $0,4 \mathrm{~V}$. Vstavljeni diagram prikazuje koncentracijo $\mathrm{H}_{2} \mathrm{O}_{2}$ v odvisnosti od toka v linearnem področju. 
inset). The high electrocatalytic activity of the graphene/ZnO nanocomposite can be ascribed to a large surface-area-to-volume ratio and the synergistic effect between graphene and $\mathrm{ZnO}$.

The amperometric current - time $(i-t)$ curve is the most often used method to evaluate the electrocatalytic activity of electrochemical sensors. The amperometric response of the graphene/ZnO nanocomposite-modified SPCE was investigated by successively adding hydrogen peroxide $\left(\mathrm{H}_{2} \mathrm{O}_{2}\right)$ to a continuously stirred PBS solution. Figure 4 clearly shows that the modified SPCE exhibits a rapid and steady response to each $\mathrm{H}_{2} \mathrm{O}_{2}$ addition, while the Figure 4 inset displays the linear relationship between the current response and $\mathrm{H}_{2} \mathrm{O}_{2}$ concentration in the range of $1 \mathrm{mM}$ to $15 \mathrm{mM}$ with a sensitivity of 0.055 $\mu \mathrm{A} / \mathrm{mM}$. The linear regression equation is $i / \mu \mathrm{A}=0.0548$ $\mathrm{C}(\mathrm{mM})+0.0547$ with a correlation coefficient $\left(R^{2}\right)$ of 0.9859 , which permits a reliable quantification of the amount of $\mathrm{H}_{2} \mathrm{O}_{2}$ in a sample.

\section{CONCLUSION}

In summary, a facile green approach for the synthesis of a graphene $/ \mathrm{ZnO}$ nanocomposite at room temperature was developed. The SEM and TEM images revealed that flower-like $\mathrm{ZnO}$ nanoparticles were homogenously distributed on the surface of the graphene sheets, while the XRD result affirms the structural integrity and purity of the as-synthesized graphene/ $\mathrm{ZnO}$ nanocomposite. The graphene/ZnO nanocomposite-modified SPCE displayed excellent electrocatalytic activity towards $\mathrm{H}_{2} \mathrm{O}_{2}$ due to the synergistic effect between graphene and $\mathrm{ZnO}$. The results herein suggest promising potentials of the graphene/ZnO nanocomposite for various sensing applications.

\section{Acknowledgments}

The Ministry of Science, Technology and Innovation research grant (E-Science code: 04-02-12-SF0198), the Early Career Research and Knowledge Transfer Scheme
Award (ECKRT: A2RHM), HIR-Chancellory UM (UM.C/625/1/HIR/079), HIR-MOHE (UM.C/625/1/ $\mathrm{HIR} / \mathrm{MOHE} / \mathrm{SC} / 06)$ and the University of Nottingham are gratefully acknowledged. The authors also express heartfelt gratitude to Professor Dino Isa for access to the SAHZ pilot plant and its analytical equipment.

\section{REFERENCES}

${ }^{1}$ K. S. Novoselov, A. K. Geim, S. V. Morozov, D. Jiang, Y. Zhang, S. V. Dubonos, I. V. Grigorieva, A. A. Firsov, Science, 306 (2004), 666-669, doi:10.1126/science. 1102896

2 J. Zhou, N. S. Xu, Z. L. Wang, Adv. Mater., 18 (2006), 2432-2435, doi:10.1002/adma.200600200

${ }^{3}$ B. N. Joshi, H. Yoon, S. H. Na, J. Y. Choi, S. S. Yoon, Ceram. Int., 40 (2014), 3647-3654, doi:10.1016/j.ceramint.2013.09.060

${ }^{4}$ R. R. Salunkhe, Y. H. Lee, K. H. Chang, J. M. Li, P. Simon, J. Tang, N. L. Torad, C. C. Hu, Y. Yamauchi, Chemistry - A European Journal, 20 (2014), 13838-13852, doi:10.1002/chem.201403649

${ }^{5}$ K. Anand, O. Singh, M. P. Singh, J. Kaur, R. C. Singh, Sensors and Actuators B: Chem., 195 (2014), 409-415, doi:10.1016/j.snb. 2014.01.029

${ }^{6}$ R. J. Chung, Z. C. Lin, P. K. Yang, K. Y. Lai, S. F. Jen, P. W. Chiu, Nanoscale Res. Lett., 8 (2013), 1-5, doi:10.1186/1556-276X-8-350

${ }^{7}$ Q. Ouyang, Z. Xu, Z. Lei, H. Dong, H. Yu, L. Qi, C. Li, Y. Chen, Carbon, 67 (2014), 214-220, doi:10.1016/j.carbon.2013.09.083

${ }^{8}$ Y. Zhu, H. I. Elim, Y. L. Foo, T. Yu, Y. Liu, W. Ji, J. Y. Lee, Z. Shen, A. T. S. Wee, J. T. L. Thong, C. H. Sow, Adv. Mater., 18 (2006), 587-592, doi:10.1002/adma.200501918

${ }^{9}$ S. Palanisamy, S. M. Chen, R. Sarawathi, Sensors and Actuators B: Chem., 166-167 (2012), 372-377, doi:10.1016/j.snb.2013.02.075

${ }^{10}$ T. Lu, Y. Zhang, H. Li, L. Pan, Y. Li, Z. Sun, Electrochim. Acta, 55 (2010), 4170-4173, doi:10.1016/j.electacta.2010.02.095

${ }^{11}$ A. Ali, K. Ali, K. R. Kwon, M. Hyun, K. Choi, J. Mater. Sci.: Mater. Electron., 25 (2014), 1097-1104, doi:10.1007/s10854-013-1693-1

${ }^{12}$ J. Wu, X. Shen, L. Jiang, K. Wang, K. Chen, Appl. Surf. Sci., 256 (2010), 2826-2830, doi:10.1016/j.apsusc.2009.11.034

${ }^{13}$ J. S. Y. Chia, M. T. T. Tan, P. S. Khiew, J. K. Chin, H. Lee, D. C. S. Bien, W. S. Chiu, Chem. Eng. J., 249 (2014), 270-278, doi:10.1016/ j.cej.2014.03.081

${ }^{14}$ Y. Y. Chan, B. Kamarudin, D. A. Ozkan, S. Y. Lee, P. Lalitha, A. Ismail, M. Ozsoz, M. Ravichandran, Anal. Chem., 80 (2008), 2774-2779, doi:10.1021/ac702333x

${ }^{15}$ M. Florescu, C. M. A. Brett, Talanta, 65 (2005), 306-312, doi:10.1016/j.talanta.2004.07.003 